\title{
APLIKASI PEMANFAATAN LIMBAH INDUSTRI BATU COBEK DI DESA TOYOMARTO SEBAGAI BATU HIAS GABION ATAU BROJONG
}

\author{
Machrus Abadi \\ Universitas Brawijaya \\ machrus_abadi@ub.ac.id
}

\begin{abstract}
Abstrak: Topographically, Toyomarto Village, Singosari District, Malang Regency, is included in the category of highland areas with an altitude of \pm 622 meters above sea level (masl). In 1981, the mortar and mortar handicrafts became the livelihood of residents in Petung Wulung hamlet, Toyomarto village, Singosari sub-district. The purpose of this service is to provide waste benefits as an economic value for local residents. Therefore, the community service team planned a concept to use mortar waste as gabion and brojong stones. In addition, increasing the economic value of the waste will also increase the attractiveness of using mortar waste as a decoration in Toyomerto village in beautifying the environment. In this community service activity 4 (four) gabion or brojong designs were produced. Among them are cylindrical, tubular, and semi-spherical or circular with a conical top for planting media and plants. It also has its own offer for the villagers apart from being a decoration for the environment, as well as a typical souvenir from the village of Toyomarto. Plants that are chosen besides their aesthetics are those that can survive indoors and outdoors and do not require much water or a continuous watering process, for example plants of the Agavesiklok, Portulaca Grandiflora, Cactus and so on. The results of the implementation of this program were well received by the community and could improve the economy of Toyomarto Village. Kata Kunci: Mortar Waste, Gabion Or Brojong, Toyomarto Village
\end{abstract}

\section{PENDAHULUAN}

Berdasarkan observasi awal yang telah dilakukan, muncul beberapa data dikutip dari toyomarto.malangkab.go.id berhubungan dengan penguatan pengembangan desa Toyomerto dalam pemanfaatan limbah batu cobek. Salah satu hal tersebut adalah sebagai batu gambion atau brojong. Hal ini bertujuan untuk memberikan manfaat limbah sebagai nilai ekonomis bagi warga sekitar. Oleh karena itu, tim pengabdian merencanakan sebuah konsep pemanfaatan limbah batu cobek sebagai batu gabion dan brojong. Selain, meningkatkan nilai ekonomis limbah juga akan meningkatkan daya tarik dari pemanfaatan limbah batu cobek sebagai hiasan desa Toyomerto dalam mempercantik lingkungan. Identifikasi masalah (1) permasalahan pemanfaatan limbah batu cobek, hal tersebut bisa ditindak lanjuti dengan mengevaluasi dan memberikan ide kreatif pembuatan brojong untuk pengurangan jumlah limbah cobek di lingkungan masyarakat (2) penghijauan dan tata artistik taman baik di rumah maupun di lingkungan desa yang perlu di tingkatkan. Sedangkan tujuan pengabdian ini untuk (1) membuat desain brojong dan memberikan workshop atau lokakarya teknik pembuatan brojong besar dan mini untuk masyarakat desa Toyomarto. (2) memberikan informasi pemilihan tanaman atau bunga untuk ditanam pada brojong.

Menurut Nasruddin Sulaiman (1993) cobek dan ulekan termasuk pasangan alat masak kuno yang sudah dipakai sejak zaman paleolithikum (zaman batu) atau 35.000 tahun sebelum masehi. Dari temuan ini sekaligus membuktikan kalau cobek dan ulekan merupakan alat tertua yang digunakan sejam zaman dulu. Para arkeolog mengungkapkan kalau artefak cobek dan ulekan kuno ini dijadikan alat untuk menumbuk. Salah satu artefak batu yang ditemukan di yunanai pada kurun waktu 3.200 sampai 2.800 tahun sebelum masehi. Conek digunakan untuk menumbuk bahan alam 
yang mengandung pigmen zat pewarna. Kini cobek dan ulekan identik sebagai alat masak untuk menghaluskan bumbu dan bahan, tetapi sebenarnya dahulu cobek bukan hanya dijadikan alat penumbuk makanan. Bukan hanya di Indonesia, alat penumbuk ini digunakan oleh manusia kuno di berbagai belahan dunia. Sedangkan Gabion terbuat dari anyaman kawat berlapis zinc heavy galvanize dengan lilitan ganda (double twist) yang membentuk lobang segi enam (hexagonal) dengan cara diikat kuat di antara sisi-sisinya. Kekuatan dari gabion sendiri terletak pada kekuatan tarik kawat (tensile strength), lapisan galvanis yang membuat kawat tidak mudah berkarat, dan kekuatan lilitan ganda pada lubang hexagonal anyaman sehingga anyaman tidak mudah terurai.

Menurut Kementerian Pekerjaan Umum (2012) fungsi atau kegunaan gabion atau brojong (1) melindungi dan memperkuat tebing tanah, baik di lereng sungai atau tanggul. Menjaga tepi sungai terhadap aliran air dan juga erosi. Namun, saat ini implementasi dari gabion ke berbagai elemen desain telah berkembang. Gabion tidak hanya sebagai aplikasi fungsional, tetapi telah jauh berkembang menjadi olahan estetis yang memiliki daya tariknya tersendiri. Kawat-kawat gabion juga telah dibuat dengan sangat beragam untuk mengimbangi pengaplikasiannya yang sudah lebih dinamis. (2) Keunggulan Gabion. Yaitu Fleksibel, dapat mengikuti pergerakan tanah di bawahnya tanpa merusak konstruksi. Tembus air, sehingga dapat mengurangi tanah aktif akibat air yang dapat mengalir melalui sela-sela bebatuan isi gabion. Selanjutnya, ekonomis, konstruksinya sederhana, dapat dikerjakan tanpa mesin berteknologi tinggi. Dapat dipasang di lingkungan yang beragam, baik di air atau tempat kering. Ramah lingkungan, bobotnya ringan dan mudah dibawa dan dapat diproduksi dengan ukuran yang disesuaikan dengan kebutuhan di lapangan. Tujuan dalam kegiatan pengabdian ini adalah meningkatkan nilai ekonomis limbah batu cobek yang ada di desa Toyomarto sebagai batu hias bentuk gabion.

\section{METODE}

a. Kerangka Pemecahan Masalah

Berbagai masalah terkait limbah home industri di desa Toyomato khususnya limbah cobek akan terselesaikan dengan adanya pemanfaatan limbah sebagai hiasan gabion atau brojong. Oleh karena itu, agar dapat terealisasikannya hal tersebut maka dibutuhkannya kerangka pemecah masalah, antara lain sebagai berikut : 1) Menjaring khalayak yang menjadi sasaran pelatihan. 2) Menjelaskan tentang potensi usaha alternatif dengan produksi gabion atau brojong. 3). Memberi pelatihan intensif pembuatan produk gabion atau brojong 4). Memberikan penyuluhan tentang tanaman hias untuk ditanam di gabion atau brojong.

b. Khalayak Sasaran

Khalayak yang menjadi sasaran umum adalah pemuda-pemudi karangtaruna. Sasaran secara khusus adalah bapak-bapak dan ibu-ibu rumah tangga pengerajin cobek di desa Toyomarto.

c. Keterkaitan

Pelaksanaan pengabdian masyarakat ini dilakukan dengan menjalin kemitraan pada karangtaruna, ibu-ibu PKK dan masyarakat desa Toyomarto Kecamatan Singosari Kabupaten Malang. Peran serta anggota PKK adalah membantu menggerakkan usaha warga dalam meningkatkan potensi dan memanfaatkan limbah home industri. Sementara peran tim akademisi adalah membantu konsep ide serta pelatihan membuat batu hias gabion dalam memberdayakan masyarakat sekitar. 
d. Metode Pelaksanaan

Metode kegiatan ini akan dilakukan sebagai berikut. 1) Observasi dan wawancara yang berguna untuk mengetahui problematika yang dihadapi pemangku desa Toyomarto. 2) Diskusi atau FGD yang bertujuan untuk merumuskan limbah home industri yang paling berpotensi dan bernilai ekonomis untuk dimanfaatkan warga. a. Pelatihan dan pembuatan batu hias gabion dari limbah batu cobek. b. Evaluasi akhir yang bertujuan untuk mengetahui hasil dan antusias partisipasi warga.

\section{HASIL KARYA UTAMA DAN PEMBAHASAN}

Pelaksanaa pengabdian masyarakat dengan judul "Aplikasi Pemanfaatan Limbah Industri Batu Cobek di Desa Toyomarto sebagai Batu Gabion atau Brojong” dapat terlaksana pada tanggal 02 September 2020. Kegiatan ini mundur dari program yang sudah direncanakan karena pandemi Covid-19 dan kegiatan warga masyarakat terkait bersih desa. Selain itu dilaksankan pada malam hari dikarenakan warga masyarakat pagi sampai sore melakukan aktifitas mencari nafkah. Akan tetapi kegiatan ini pada akhirnya tetap berjalan dengan lancar.

Sebagaimana analisis kebutuhan, pemilihan tema kegiatan pemanfaatan limbah cobek menjadi pembuatan gabion atau brojong di Desa Toyomarto ini juga merupakan upaya dalam meningkatkan kewirausahaan masyarakat desa dengan menggali potensi kelokalan desa. Hal ini dilakukan sebagai alternatif peningkatan ekonomi masyarakat dalam tantangan global. Sebagaimana pandangan Kertajaya (2006) bahwa salah satu kunci sukses untuk bersaing dalam bisnis global adalah strategi glorecalization, yakni memadukan nilai global yang konsisten dengan strategi regional yang terkoordinasi dengan taktik lokal yang dikembangkan secara spesifik dari daerah. Dalam hal ini kelokalan merupakan kunci, memadukan sesuatu yang global dengan lokal ataupun mengangkat kelokalan menjadi pembeda atau penanda yang bernilai tinggi untuk diglobalkan.

Sementara itu, masyarakat desa Toyomarto telah memiliki kekhasan dengan produksi cobek yang terkenal dari Malang. Maka dari itu pelatihan pengolahan dari limbah cobek yang menumpuk di lingkungan masyarakat bisa dilakukan dengan membuat gabion atau bronjong yang ditanam oleh bunga atau tanaman hias untuk menghias instalasi ruangan bahkan taman desa Toyomarto itu sendiri. Dari Program pengabdian masyarakat yang telah dilakukan dapat menghasilkan beberapa produk. Produk yang pertama berupa kerangka desain gambar dalam membuat seni hias batu bronjong, untuk produk kedua yaitu berupa video tutorial serta alat- alat yang dibutuhkan pembuatan batu bronjong, sedang yang terakhir adalah berupa prototipe batu hias bronjong.

Pelatihan pembuatan gabion atau brojong diteruskan sampai tahap pembuatan video tutorial yang di unggah di sosial media, dan bisa diputar kembali videonya ketika masyarakat desa Toyomarto memerlukan kembali untuk pelatihan pada generasi berikutnya. Selain hal tersebut, kegiatan pemanfaatan limbah cobek menjadi gabion atau brojong dengan bunga bisa menjadi merchandisesebagai ikon desa Toyomarto.

Pelaksanaan kegiatan dibuka dengan sambutan oleh Kepala Dusun Petungwulung dan di lanjutkan sambutan oleh anggota pengabdian masyarakat yaitu Nur Iksan, M.Sn. Kemudian dilanjutkan dengan pemaparan pembuatan gabion atau brojong yang sudah berpengalaman yakni Bapak Sugeng Pribadi (Klemin). Selanjutnya dilakukan dengan praktik pelatihan pembuatan gabion atau brojong dan yang terakhir adalah penanaman bunga di gabion atau brojong tersebut. 


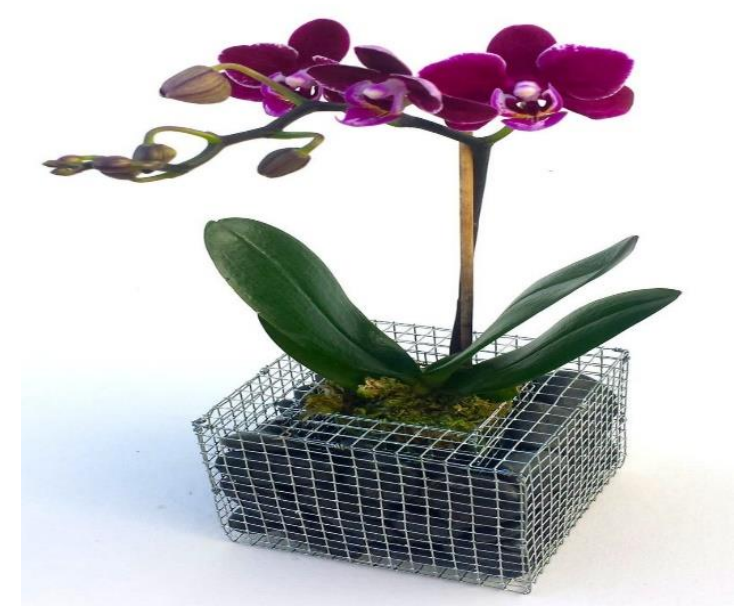

Gambar. Hasil akhir pembuatan gabion atau brojong

\section{a. Hasil Produk Desain Gabion atau Brojong}

Hasil dalam program pengabdian masyrakat di desa Toyomarto adalah menhasilakn sebuah produk desain batu gabion. Sejalan dengan hal tersebut, produk ialah hasil proses produksi yang dilakukan oleh produsen atau perusahaan yang nantinya akan diperjual-belikan kepada konsumen yang membutuhkan. Tidak menutup kemungkinan setiap hasil pembuatan gabion atau brojong ini juga dapat diperjualbelikan di pasaran. Batu hias gabion atau brojong merupakan sebuah subtansi yang diproduksi oleh produsen dari pemanfaatan limbah batu cobek dan ditawarkan ke suatu pasar untuk memenuhi kebutuhan konsumen sebagai produk khusus. Hal tersebut dipertegas dengan pendapat Kotler dan Amstrong (1996:274) "A product as anything that can be offered to a market for attention, acquisition, use or consumption and that might satisfy a want or need".

Saat ini nilai sebuah produk tidak hanya menfaatnya saja yang diutamakan, namun adanya nilai estetika dari desain produk yang diperlihatkan. Desain produk adalah suatu kreatifitas dalam memecahkan masalah dengan target yang jelas. Dalam hal ini, sebuah desain pada barang produksi tidak hanya sebuah rancangan di atas kertas belaka namun lebih mengutamakan proses dari awal hingga akhir dengan melibatkan rancangan, gagasan yang harus terwujud serta memiliki nilai estetika yang tinggi. Desain produk menggambarkan proses membayangkan, menciptakan dan mengulangi produk yang memecahkan masalah pengguna atau memenuhi kebutuhan spesifik.

Beberapa alasan mengapa desain produk gabion atau brojong ini sangat penting sebelum eksekusi. 1) Menghindari kegagalan-kegagalan yang mungkin terjadi dalam pembuatannya, proses pendesainan produksi sangatlah penting karena dengan adanya desain akan meminimalisir kegagalan saat proses produksi berlangsung. 2) Dapat memilih metode yang paling baik dan ekonomis dalam pembuatan produk, desain dalam manajemen produksi di fungsikan untuk perencanaan pra-produksi sehingga produsen dapat menentukan metode produksi apa yang paling baik pada saat produksi yang sesuai dengan kebutuhan mereka. 1) Dapat menentukan standarisasi atau spesifik produk yang dibuat, hal ini berkaitan erat dengan mengetahui kelayakan produk tersebut apa sudah memenuhi persyaratan atau masih perlu diperbaiki kembali. 2) Dapat menghitung biaya dan menentukan harga produksi dibuat. 3) Untuk membuat produk seekonomis mungkin dalam penggunaan bahan baku dan biaya-biaya dengan tanpa mengurangi nilai jual produk tersebut. 
Hasil Produk desain gambar gabion terdiri atas tiga jenis desain. Desain yang pertama berbentuk oval panjan, sedang untuk desain kedua berbentuk setengah lingkaran dan yang terakhir berbentuk kotak segi empat. Ketiga desain tersebut dibuat dengan ukuran dan biaya seminimal mungkin sehingga dapat memudahkan masayarakat untuk mengaplikasikannya.

Maka, bisa dipastikan pemanfaatan limbah batu cobek ini menjadi batu hias gabion atau brojong dengan finishing berupa tanaman cantik bisa meningkatkan sektor ekonomi di masyarakat Toyomarto itu sendiri. Sebelum ke tahap pelatihan pembuatan gabion atau brojong, tim pengabdian membuat desain gabion atau brojong terlebih dahulu. Berikut ini merupakan desain gabion atau brojong yang akan di sosialisasikan kepada warga masyarakat dalam loka karya atau workshop.

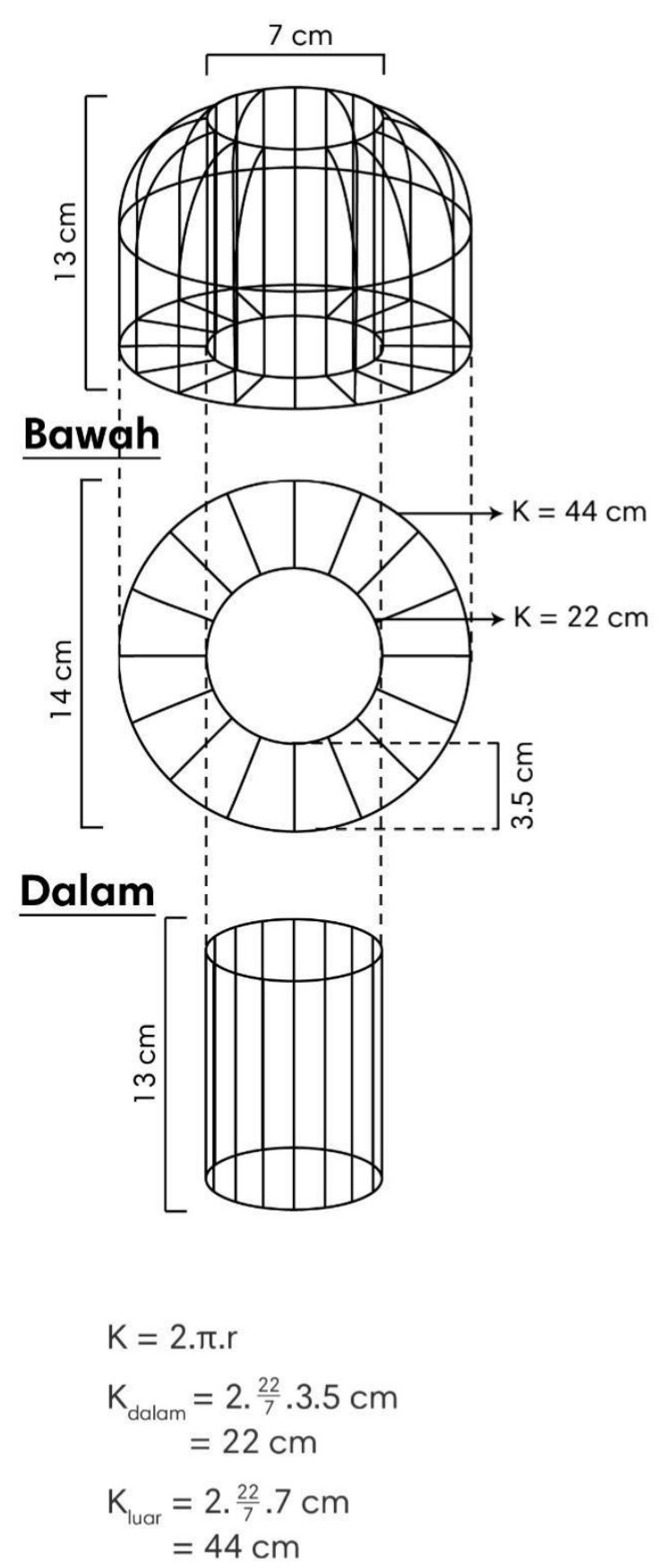

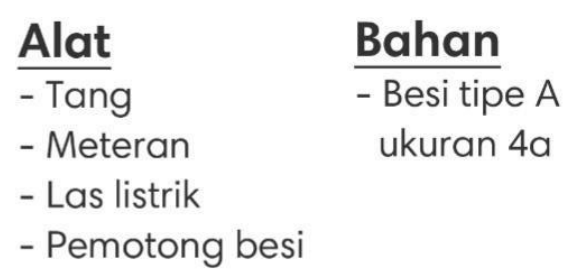

\section{Langkah}

1. Potong besi dengan ukuran yang telah ditentukan.

2. Bengkokkan besi, sambungan dilas<smiles>C1CCCCCC1</smiles>

3. Sambungkan besi yang sudah membentuk lingkaran untuk bagian dalam

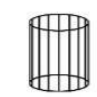

4. Dilanjutkan dengan menyambungkan bagian poin 3 yang sudah selesai dengan kerangka bagian luar

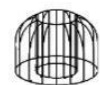

5. Berikan besi melingkar kembali pada bagian tengah supaya lebih kuat

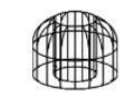

6. Masukkan batu melalui bagian bawah. setelah selesai, potongan besi ukuran $\pm 3,5$ $\mathrm{cm}$ untuk bagian bawah

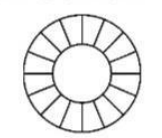

Gambar 1. Desain A dan langkah-langkah pembuatan gabion atau brojong. 
PEDULI: Jurnal Ilmiah Pengabdian Pada Masyarakat, 2020, Vol.4, No.2

ISSN: 25974653. EISSN:25974688

http://peduli.wisnuwardhana.ac.id/index.php/peduli/index

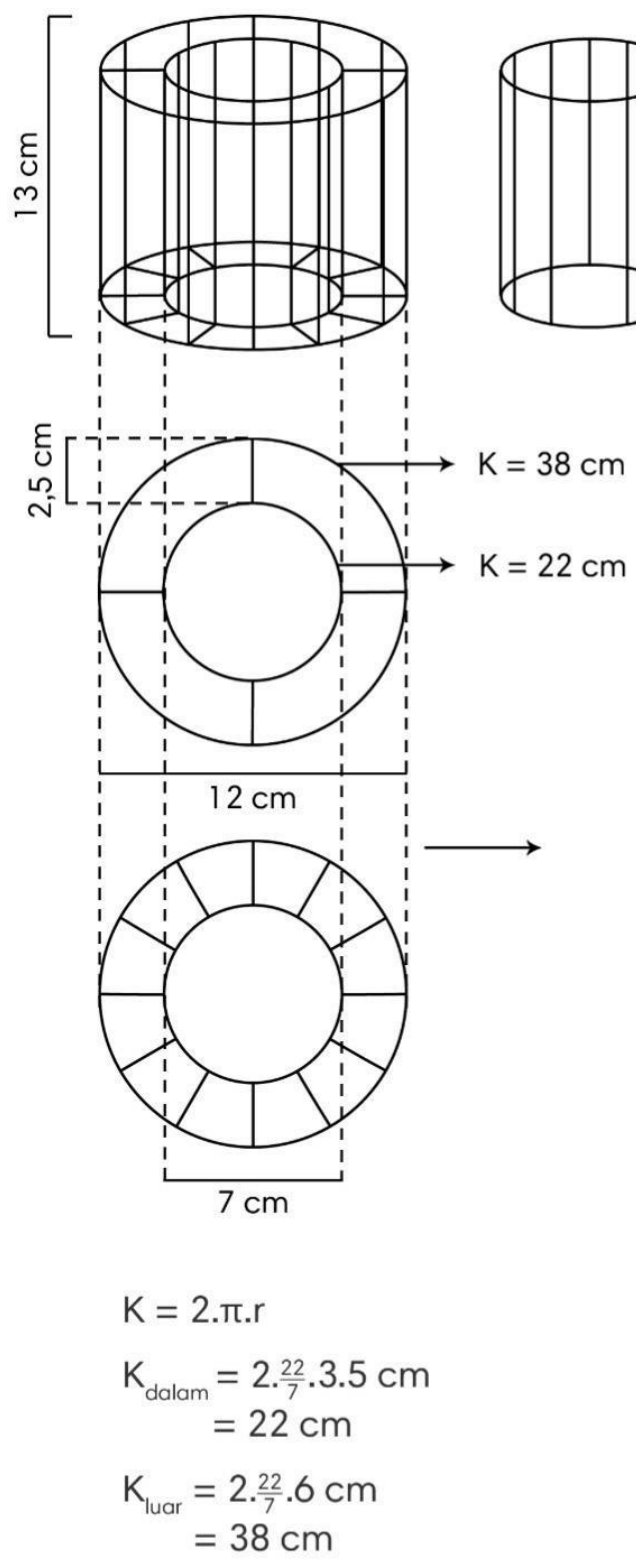

Alat

- Tang

- Meteran

- Las listrik

- Pemotong besi

\section{Bahan}

- Besi tipe A ukuran $4 a$

\section{Langkah}

1. Potonglah besi dengan ukuran yang telah ditentukan.

2. Setelah selesai pemotongan besi, bengkokkan besi menjadi melingkar untuk bagian atas dan bawah, kemudian disambungkan menggunakan las.

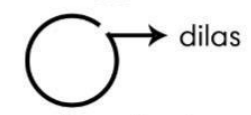

3. Sambungkan lingkaran atas dan bawah.

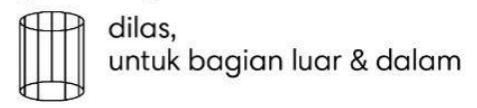

4. Sambungkan besi dengan cara dilas apabila point 3 sudah selesai.

Atas

Bawah

5. Masukkan batu melalui bagian atas.

Gambar 2. Desain B dan langkah-langkah pembuatan gabion atau brojong 
PEDULI: Jurnal Ilmiah Pengabdian Pada Masyarakat, 2020, Vol.4, No.2

ISSN: 25974653. EISSN:25974688

http://peduli.wisnuwardhana.ac.id/index.php/peduli/index

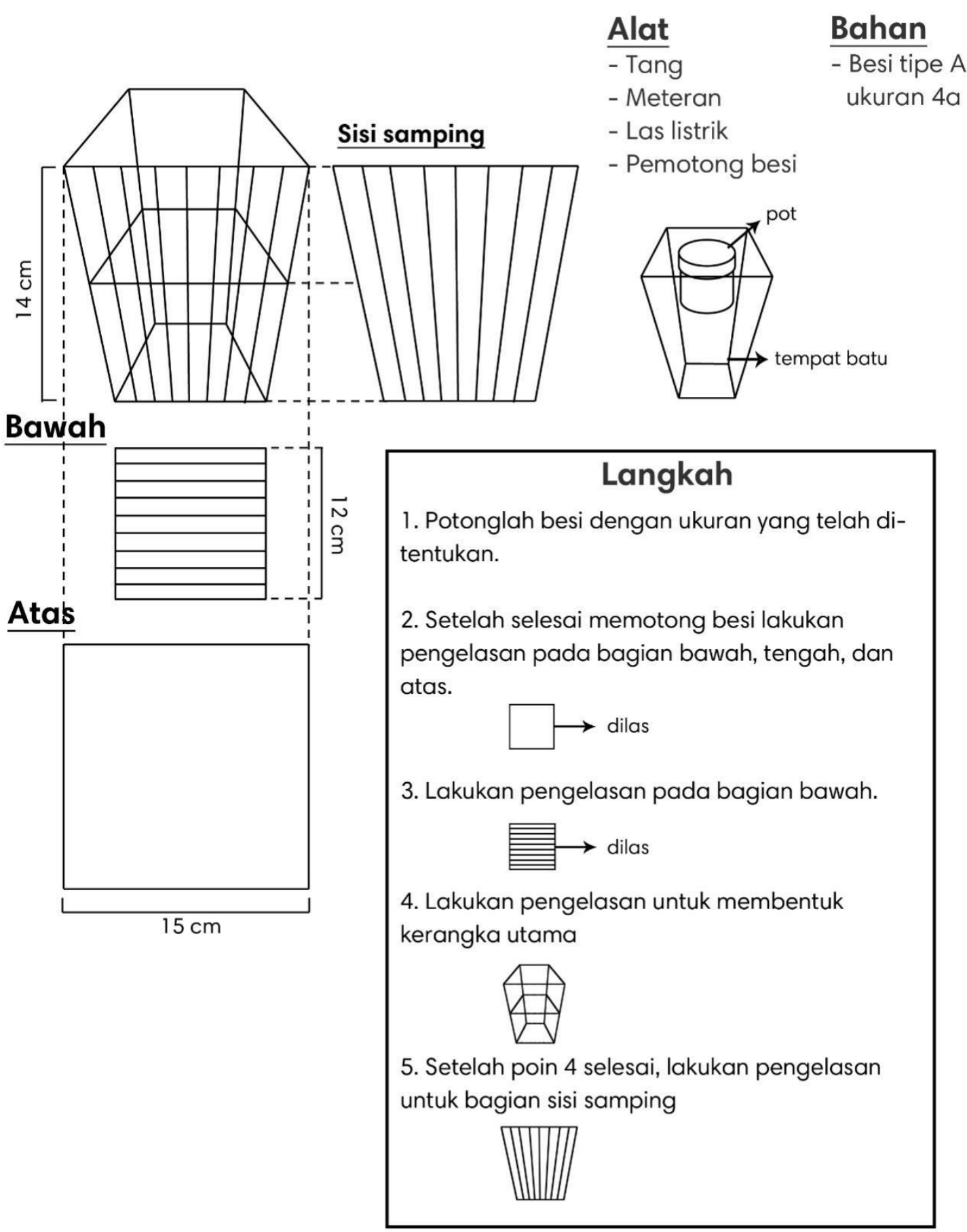

Gambar 3. Desain C dan langkah-langkah pembuatan gabion atau brojong. 


\section{b. Pembahasan Pembuatan Gabion atau Brojong}

Sebelum melakukan pelatihan, tim pengabdian membuat desain gabion atau brojong. Setelah itu dilaksanakannya pelatihandi rumah bapak Hartono yakni Kepala Dusun Petungwulung,Desa Toyomarto, Kecamatan Singosari Kabupaten Malang. Peserta dalam kegiatan ini adalah bapak-bapak yang berkerja sebagai pengerajin cobek dan sebagian kecil ibu-ibu rumah tangga serta beberapa anggota karangtaruna dusun. Peserta berjumlah 21 orang, dan secara bergantian mempraktikkan pembuatan gabion atau brojong.

Pelatihan ini melibatkan tenaga ahli yang berkompeten dalam karya seni metal dengan teknik las. Pengisi pelatihan tersebut melatih secara langsung pembuatan gabion atau brojong.

Kegiatan pelatihan membuat gabion atau brojong dilakukan di ruangan terbuka, yang dimana memiliki akses udara bagus. Hal itu disebabkan penggunaan las untuk mengelas atau menyatukan kawat brojong (kawat yang berdiameter tebal), sehingga menghasilkan percikan api dan asap yang dapat membuat kulit ketat atau kering, sesak nafas dan mata yang pedih. Sehingga perlunya kehati-hatian dalam penggunaan las khususnya teknik mengelas untuk menghindari hal terburuk ke anggota tubuh.

Alat dan bahan yang disiapkan oleh tim pengabdian adalah : (1) Las listrik dengan daya 450 watt, (2) Kawat Brojong 25x25 cm, (3) Kawat Patri, (4) Jenis kawat las penyambung(Welding Rod), (5) Tang kombinasi (Linesmas), (6) Tang potong (Digonal), (7) Tang lancip (Long Nose), (8) Limbah batu cobek, (9) Media tanam, (10) Pot Bunga, (11) Bunga.

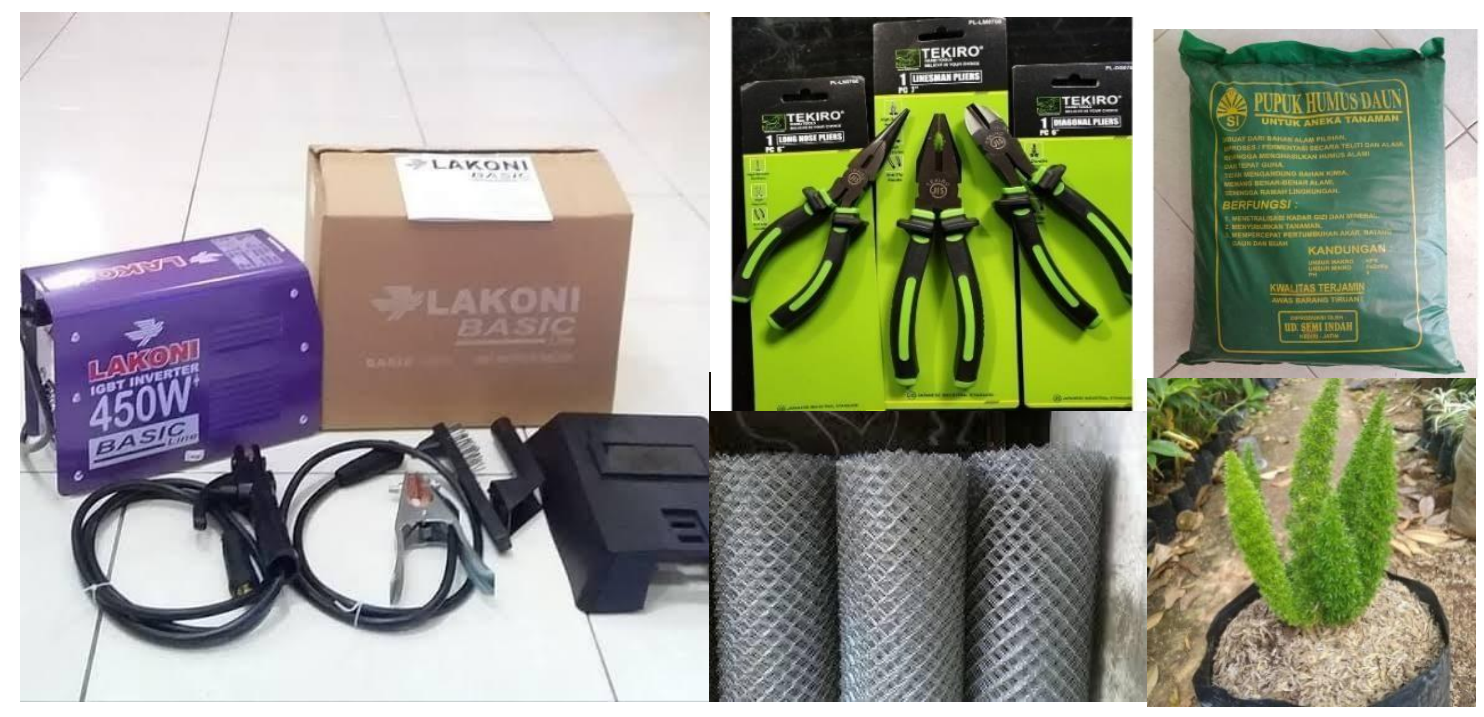

Gambar 4. Bahan dan Alat Pembuatan Gabion atau Brojong

Cara membuat gabion atau brojong adalah sebagai berikut : (1) membuat desain gabion atau brojong yang akan dibuat, (2) membuat pola di kawat brojong, (3) memotong kawat brojong sesuai dengan pola yang dibuat, (4) merangkai kawat brojong yang sudah dipotong dengan tang pemotong sesuai dengan desain, (5) teknik ini dengan dua pola, yaitu untuk kawat brojong berdiameter kecil yaitu dengan mengikat kawat bronjong dengan kawat patri; sedangkan untuk kawatt brojong besar dengan menggunakan teknik las, yang dimana kawat brojong disambung dengan kawat las 
penyambung (Welding Rod), (6) setelah jadi rangka gabion atau bronjongnya bisa diisi dengan limbah batu cobek, (7) meletakkan pot yang telah diberi media tanam dan sekaligus ditanami tanaman hias atau bunga.

Perlakuan ketika brojong sudah jadi adalah dengan pemberian pot yang sudah diberikan media tanam serta tanaman yang dipilih sesuai dengan fungsi dan tempatnya. Pemilihan tanaman sangat diperlukan, dengan mempertimbangkan ketahanan tanaman baik di dalam ruangan maupun di luar ruangan.

Setelah pelatihan pembuatan rangka gabion atau brojong selesai, kegiatan selanjutnya adalah testimoni dan pemaparan tentang tanaman yang di tanam pada gabion atau brojong. Pemaparan ini dilakukan oleh dosen Seni Rupa Murni dan kegiatan diakhiri dengan kesepakatan atas permintaan warga masyarakat untuk dibuatkan video tutorial (materi pelatihan) dan serah terima peralatan dan bahan kepada warga masyarakat Dusun Petungwulung, Desa Toyomarto, Kecamatan Singosari Kabupaten Malang secara simbolik oleh anggota pengabdian masyarakat.

\section{c. Rekomendasi Jenis Tanaman untuk Gabion atau Brojong}

Kewirausahaan merupakan gabungan kreativitas, inovasi dan ketepatan menghadapi resiko yang dilakukan dengan cara kerja keras untuk membentuk dan memelihara usaha baru. Untuk itu, beberapa strategi perlu dilakukan untuk keberhasilan tersebut. Kreativitas, inovasi dan ketepatan pengelolaan resiko tidak hanya diterapkan pada produksi saja. Hal ini juga perlu diterapkan pada strategi pemanis produksi sebagai daya tarik dari pemasaran.

Pemilihan jenis tanaman untuk gabion atau brojong perlu dipertimbangkan, karena hal sepele tetapi bisa mempengaruhi penampilan secara utuh dari gabion atau brojong tersebut. Tanaman yang ditanam merupakan finishing gabion atau brojong yang dibuat, dengan mempertimbangkan hal tersebut, gabion atau brojong yang terlihat remeh temeh bisa menjadi daya tarik sendiri dan memiliki nilai jual tinggi. Tidak bisa dipungkiri, banyak pecinta bunga atau tanaman tertentu (kolektor) memburu tanaman untuk dimilikinya, sehingga penentuan jenis tanaman bisa meningkatkan harga jual gabion atau brojong apabila difungsikan sebagai merchandise.

Beberapa rekomendasi tanaman untuk gabion atau brojong, yaitu. 1) Agavesiklok (Agave Attenuta) Tanaman hias dengan ciri khas berupa daun yang runcing dengan warna putih di pinggir daun-daunnya ini merupakan salah satu jenis tanaman hias yang cukup banyak dijumpai pada tanaman minimalis. Tanaman Agavesiklok merupakan tanaman yang tahan panas, karena tanaman tersebut bersifat sekulen atau mampu menyimpan cadangan makanan dan air. Layaknya kebanyakan tanaman sekulen, daun Agave tebal dan sedikit kaku. Warnanya mulai dari hijau tua, hijau muda, hingga kuning. Biasanya dipercantik dengan garis kuning atau putih di tepi daunnya. Oleh karena itu tanaman ini banyak diburu kolektor. Tanaman ini menyukasi sinar matahari, jadi tidak perlu takut menempatkannya di area terbuka yang terkena sinar matahari dalam waktu relatif lama. Agave dapat bertahan tumbuh pada tanah yang kering dalam waktu relatif lama. Cocok untuk indoor maupun outdoor. 

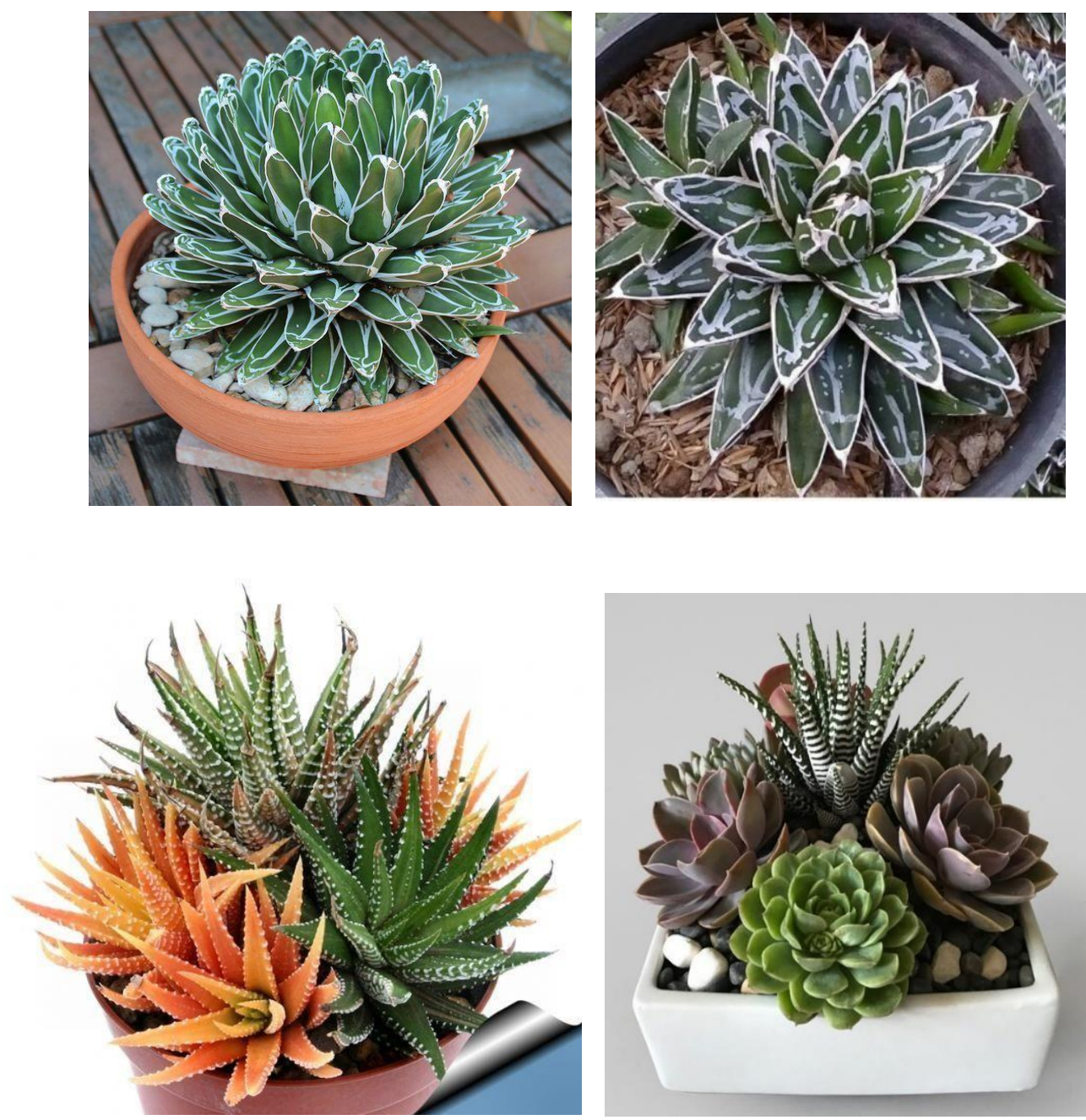

Gambar 5. Tanaman Agaveisklok (Agave Attenuta)

Alasan rekomendasi tanaman Agaveisklok adalah (1) Agave mudah ditanam dan tidak memerlukan perawatan ekstra, (2) tanaman ini banyak diburu kolektor karena keunikan dan keindahan warna maupun bentuk daun siklok ini. Sehingga bagus untuk dibudidayakan di desa Toyomarto agar dapat menarik konsumen ataupun kolektor tanaman untuk datang, (3) cara pemeliharaannya tidak begitu sulit, karena tanaman ini tidak perlu sering disirami. 2) Lidah Mertua (Sansevieria) Tanaman lidah mertua memiliki tampilan yang cantik sehingga sangat cocok digunakan untuk mempermanis tampilan dalam rumah. Tanaman yang dikenal dengan nama latin Sansevieria ini merupakan tumbuhan tropis dari Afrika Barat yang mudah sekali tumbuh. Dibalik tampilannya yang rupawan, lidah mertua memiliki banyak manfaat yang belum diketahui orang banyak, yakni sebagai berikut: (1) menyerap polusi udara, (2) menetralkan aroma yang tidak sedap, (3) mengurangi radiasi, (3) mengurangi sick bulding syndrome, (4) memiliki kemampuan menyerap polutan tinggi, (5) menyembuhkan sakit kepala, dengan membakar daun dari tanaman lidah mertua ini untuk dijadikan jamu. Manfaat di tersebut menjadikan kami untuk merekomendasikan untuk ditanam pada gabion atau brojong di desa Toyomarto. 
3) Sri Rezeki atau Chinese Evergreen (Aglaonema) Tanaman ini merupakan tanaman hias populer dan sedang diburu oleh kolektor tanaman hias yakni dari suku talastalasan atau Araceae. Genus Aglonema memiliki sekitar 30 spesies. Pecinta tanaman hias sangat menyukai si "ratu daun" ini karena kecantikan bentuk dan warnanya yang memanjakan mata.

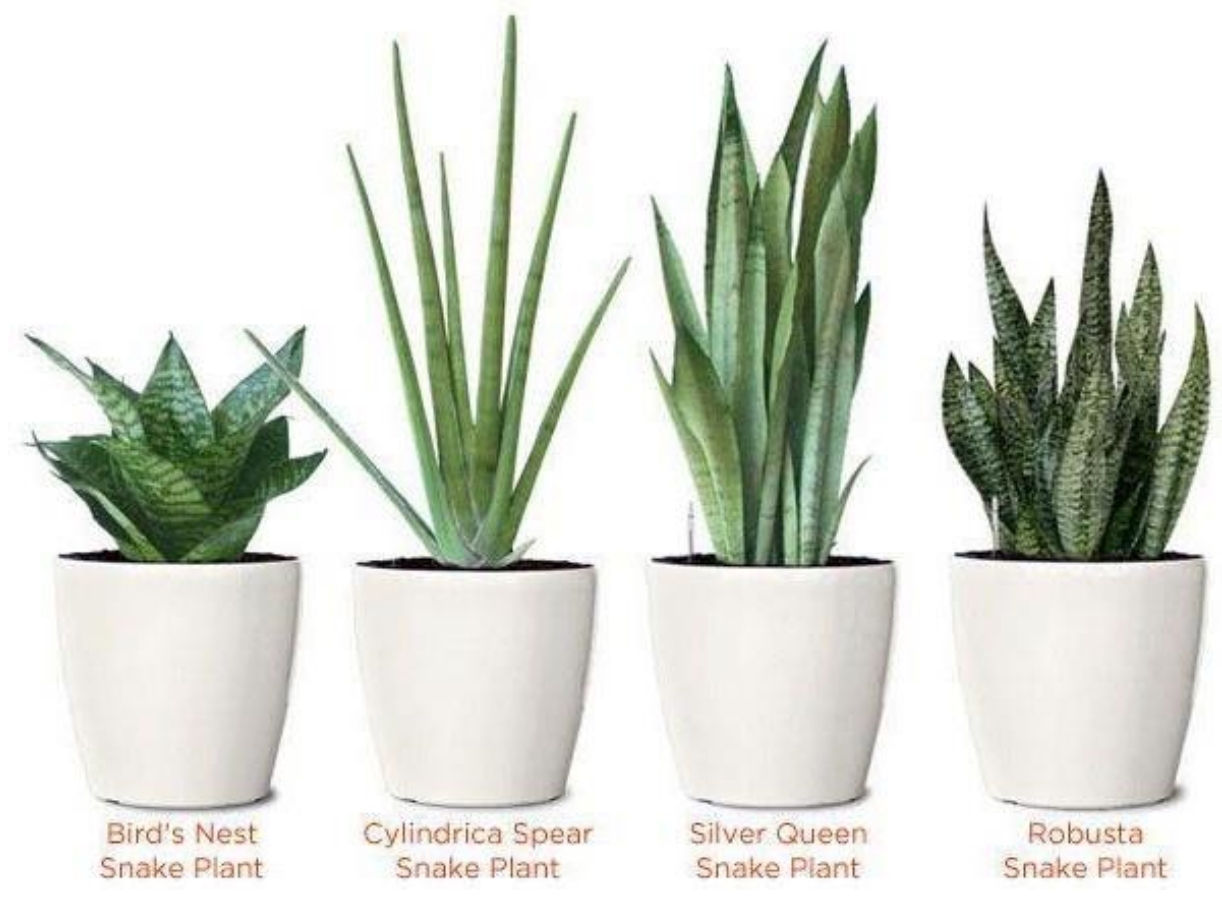

Gambar 6. Jenis tanaman lidah mertua atau Sansevieria

Selain itu, tanaman Aglonema mampu menoleransi hampir setiap kondisi dalam maupun luar rungan. Dirilis tahun 1983 oleh Gregori Garnadi Hambali, ciri-ciri dari aglonema ini memiliki daun berbentuk elips memanjang. Daunnya memiliki perpaduan warna merah, tangkai daun berwarna merah, putih atau albino, hijau muda dengan bercak-berak daun berwarna lebih terang maupun lebih terang, sehingga tanaman ini tampak eksotis jika dilihat dari segi estetika tanaman hias. Tanaman yang terkenal dengan nama Sri Rezeki ini memiliki arti mempesona, berupa simbol keberanian, keberuntungan dan kemakmuran.

\section{KESIMPULAN}

Secara umum, kegiatan pengabdian masyarakat dengan judul Aplikasi Pemanfaatan Limbah Industri Batu Cobek di Desa Toyomarto sebagai Batu Hias Gabion atau Brojong berjalan lancar. Adapun kendala-kendala yang dihadapi di lapangan tidak terlalu berdampak signifikan terhadap kegiatan tersebut. Kegiatan yang dilaksanakan tanggal 02 September 2020 ini mendapat sambutan baik dan antusias dari masyarakat dusun Petungwulung, desa Toyomarto, Kecamatan Singosari Kabupaten Malang.

Target sasaran yakni pemuda-pemudi karangtaruna, bapak-bapak pengerajin cobek dan ibu-ibu PKK sebagai peserta pelatihan memenuhi sasaran. Dalam pelatihan tersebut beberapa diantaranya memiliki niat yang serius untuk menekuni peluang bisnis pemanfaatan limbah industri batu cobek sebagai produk batu hias gabion atau brojong 
PEDULI: Jurnal Ilmiah Pengabdian Pada Masyarakat, 2020, Vol.4, No.2

ISSN: 25974653 . EISSN:25974688

http://peduli.wisnuwardhana.ac.id/index.php/peduli/index

dengan langkah sebagaimana yang telah disampaikan secara langsung (workshop)maupun melalui video atau materi pelatihan.

Secara umum, kegiatan pengabdian masyarakat Aplikasi Pemanfaatan Limbah Industri Batu Cobek di Desa Toyomarto sebagai Batu Hias Gabion atau Brojong berjalan lancar. Adapun kendala-kendala yang dihadapi di lapangan tidak terlalu berdampak signifikan terhadap kegiatan tersebut. Kegiatan yang dilaksanakan tanggal 02 September 2020 ini mendapat sambutan baik dan antusias dari masyarakat dusun Petungwulung, desa Toyomarto, Kecamatan Singosari Kabupaten Malang. Target sasaran yakni pemuda-pemudi karangtaruna, bapak-bapak pengerajin cobek dan ibu-ibu PKK sebagai peserta pelatihan memenuhi sasaran.

\section{DAFTAR PUSTAKA}

Adjid, D.A., 1994. Sistem dan Strategi Pengembangan Agribisnis. Badan Agribisnis Departemen Pertanian. Pidato Pengarahan pada Pembukaan Seminar Nasional Dalam Rangka Dies Natalis UJ XXX dan Lustrum VI. Jember. 10 September 1994.

Anonim, 1988. Budidaya Dan Bisnis Bunga. Tumbuh I (2) : 35.

Anonim, 2000. Agriculture Experiment Station Sunflower.

Anonim, 2010. Tanaman Hias. http://duniatanaman.com/perkembangbiakantanaman.html. Diakses $12 \mathrm{Mei}$ 2012.

Anonim. 2000. Sunflowers (Helianthus sp). http://ipm.ucanr.edu/PMG/WEEDS/sunflowers.html. Diakses 12 November 2016.

Anonim. 2016. Kembang Kertas. http://www.generasibiologi.com/2016/03/botanikembang-kertas-zinnizelegans.html. Diakses 28 Desember 2016.

Aprilia, D., 2017. Budidaya Tanaman Gerbera (Gerbera jamesonii). Laporan Magang Profesi Di PT. Wahana Kharisma Flora, Malang, Jawa Timur. Prodi Agroteknologi. Fakultas Pertanian. UMY. Yogyakarta.

Bagianto, 1993. Harus Berhasil Atasi Kendala Pengembangan Hortikultura. Agrobis I (31). 17.

Balai Penelitian Tanaman Hias. 2012. Potensi Tanaman Hias Tropis. Pustaka Litbang Departemen Pertanian. Cianjur.

BBPP, 2016. http://www.bbpp lembang.info/index.php/en/arsip/artikel/artikelpertanian/502tanaman- bungatasbih\#jacommentid:16. Diakses 23 Desember 2016. Bronjong. Badan Penerbit Dep.PU

Chapman, S. R. and L. O. Carter. 1975. Crop Production. W. H. Freeman and Company. San Fransisco. Darmansyah, A., 1993. Pola Konsumsi Hortikultura Indonesia Masih Di Bawah Standar. Agrobis I (21) : 18

Haryanti, Trini. 2014. (Online) http://www.triniharyanti.id/2014/02/membangunbudaya-literasi-dengan.html, (diakses 26 April 2018) http://www.uaex.edu/farmranch/horticulture/ornamentals/weed_id/default. htm. Diakses 12 November 2016.

Kertajaya, Hermawan. 2006. Hermawan Kertajawa on Marketing. Yuswohady, Bembi Dwi Indrio, Sunarto Ciptoharjono (eds). Jakarta: Gramedia.

Kotler, P dan G. Amstrong. 2004. Dasar-Dasar Pemasaran. Edisi Kesembilan. Jakarta: Penerbit Indexs. 
Macaveri. Gabion. Malang: Macaveri.

Nasruddin Sulaiman, Drs. Rusdi Sufi , Drs. A. Hamid Ali. 1993. Dapur Dan Alat-Alat Memasak Tradisional Propinsi Daerah Istimewa Aceh, Departemen Pendidikan Dan Kebudayaan Milik Depdikbud Tidak Diperdagangkan

Pekerjaan Umum. Kementerian. 2012. Modul: Pelaksanaan Pekerjaan Bronjong Buku Informasi Edisi: 1-2012. Jalan Sapta Taruna Raya, Komplek PU Pasar Jumat Jakarta Selatan.

Proyek Penyusunan Standar Perencanaan dan Buku Pedoman Pengairan. 1983.

Toyomarto, Desa. 2015. Profil Desa Toyomarto, (Online), http:// http://desatoyomarto.malangkab.go.id/desa/, (diakses 26 April 2020) 